\section{Pre-invasive cervical disease and uterine cervical cancer in Brazilian adolescents: prevalence and related factors}

\author{
Doença cervical pré-invasiva e câncer \\ cérvico-uterino em adolescentes brasileiras: \\ prevalência e fatores associados
}

Denise Leite Maia Monteiro 1,2 Alexandre José Baptista Trajano ${ }^{3}$ Kátia Silveira da Silva 1

Fábio Bastos Russomano 1

\footnotetext{
${ }^{1}$ Instituto Fernandes Figueira, Fundação Oswaldo Cruz, Rio de Janeiro, Brasil. 2 Ambulatório de Ginecologia para Adolescentes, Hospital Geral de Jacarepaguá, Rio de Janeiro, Brasil. 3 Centro Biomédico, Universidade do Estado do Rio de Janeiro, Rio de Janeiro, Brasil.

Correspondence D. L. M. Monteiro Instituto Fernandes Figueira, Fundação Oswaldo Cruz. Av. Rui Barbosa 716, Rio de Janeiro, $R J$ 22250-020, Brasil. denimonteiro2@yahoo.com.br
}

\begin{abstract}
The objective was to describe the prevalence and factors associated with uterine cervical cancer (CA) and high-grade squamous intraepithelial lesions (HSIL) in adolescents. A cross-sectional study was carried out with 702 sexually active adolescents treated at a general hospital in Rio de Janeiro, Brazil, from 1993 to 2002. Screening was performed by cytopathology and colposcopy and confirmation by biopsy. Exposure variables were socio-demographic characteristics and those related to reproductive health, habits, and sexual behavior. Adjusted odds ratios were estimated using multivariate logistic regression analysis. Based on histopathology, the prevalence of HSIL/CA was 3\% (95\%CI: 1.8-4.6). There was one case of invasive cancer. With each additional pregnancy, the odds of HSIL/CA increased by 2.2 (95\%CI: 1.1-4.4). Age was also associated with this outcome, doubling the odds of acquiring this degree of disease with each year of age $(O R=2.0 ; 95 \% C I: 1.2-3.4)$. The prevalence of lesions suggests the importance of including sexually active adolescent females in cervical cancer screening programs aimed at early detection and treatment of these lesions.
\end{abstract}

Uterine Cervical Neoplasms; Human Papillomavirus; Adolescent

\section{Introduction}

Worldwide, cervical cancer is one of the most frequent malignant neoplasms in women, with 400,000 cases diagnosed per year, second only to breast cancer 1,2,3. In Brazil, 20,690 new cases are expected in 2005, with a risk of 22 cases per 100,000 women. It is the most common neoplasm in the North of Brazil $(23 / 100,000)$. In the South $(31 / 100,000)$, Central West $(23 / 100,000)$, Southeast $(22 / 100,000)$, and Northeast $(18 / 100,000)$ it is the second most frequent tumor, and every day ten women die from this disease 4

In 1996, the Brazilian Ministry of Health, with consultancy from the Ontario Cancer Treatment and Research Foundation (Canada), drafted the National Cervical Cancer and Breast Cancer Program (known as Programa Viva Mulher), which was implemented in 1997 5,6. Since the highest incidence of cervical cancer is from 35 to 49 years of age, the Program extended the safety range by ten years (above and below) so as to conduct activities targeting women from 25 to 59 years 6 .

However, the first infection with human papillomavirus (HPV) generally occurs at the beginning of sexual activity 7,8 , and since sexual debut has occurred at increasingly early ages, this creates a window of approximately ten years between contact with the virus and the first Pap smear.

Many cases of HPV infection do not cause symptoms and resolve spontaneously 9 . However, persistent cases may develop into precursor 
lesions for cervical cancer. The American Social Health Association estimates that three out of four American women from 15 to 49 years of age are infected by genital HPV at some stage in their lives 10 .

Prevalence of HPV-induced intraepithelial lesions has increased in recent decades, and the mean age at diagnosis has decreased, with increasing frequency among adolescents and women younger than 3011 . Bjørge et al. 12 observed 5\% LSIL (low-grade squamous intraepithelial lesions) prevalence among adolescents, and $7 \%$ in women from 20 to 29 years. Sadegui et al. 13 reviewed 194,000 cytopathological exams and observed peak prevalence of SIL (squamous intraepithelial lesions) between 20 and 24 years, supporting the hypothesis that the process begins during adolescence. This fact could lead to an increase in the incidence of cervical cancer in the coming years, thus posing a major challenge for public health 9,14 .

The current study resulted from ten years of work with gynecological treatment of adolescents at the Cardoso Fontes Municipal Hospital in Rio de Janeiro, Brazil, beginning in 1993. Since 1991, this hospital has operated an Adolescent Health Department, providing comprehensive and multidisciplinary care for adolescents of both sexes.

During this period, the mean age at sexual debut decreased, while the incidence of sexually transmitted diseases (STD) increased. As a probable consequence of this trend, we observed the occurrence of squamous intraepithelial lesions, including cases of pre-invasive cervical disease among adolescent girls and even one case of cervical cancer in an 18-year-old patient. This observation motivated the current study, which aims to establish the prevalence of pre-invasive cervical disease in this group and study the factors associated with the development of these lesions.

\section{Methods}

The study population consisted of adolescent females from 12 to 19 years of age, the majority referred to us by the Adolescent Health Department. The sample thus came from a larger general outpatient population with a large demand by adolescents prior to sexual debut (56.5\%).

The study design was cross-sectional. Inclusion criteria were sexual activity and having submitted to cytopathological examination. Files from all 1,616 adolescents treated from 1993 to 2002 were reviewed, and we selected the 702 who met these criteria. Diagnoses of squamous intraepithelial lesions (SIL) used the classical triad: cytopathology, colposcopy, and histopathology of the uterine cervix. Whenever cytopathology was positive for SIL, the adolescent was submitted to colposcopy. When the latter was abnormal, a targeted biopsy of the uterine cervix was performed, except for cases in which the alterations were very mild, in which case a biopsy would not be ethically justifiable.

Excluded from the final sample were 34 adolescents who had lesions already evidenced by cytopathology, but who did not have diagnostic confirmation by biopsy.

To analyze the factors associated with pre-invasive and invasive disease of the uterine cervix (high-grade squamous intraepithelial lesions HSIL/CA), the result of the evaluation of the cervix was categorized in two groups, according to the following criteria:

- Positive for high-grade lesions or cancer: biopsy showing HSIL or cancer.

- Negative for high-grade lesions or cancer: (a) negative cytology; (b) positive cytology and negative biopsy with satisfactory colposcopy; (c) LSIL cytology without biopsy with negative satisfactory colposcopy and new negative cytology after one year; (d) LSIL or HSIL cytology and LSIL biopsy; (e) LSIL cytology with colposcopy with minor alterations and without biopsy.

We used Epi Info (Centers for Disease Control and Prevention, Atlanta, USA) and SPSS (SPSS Inc., Chicago, USA) for statistical analysis. The statistical significance of associations was assessed using chi-square $\left(\chi^{2}\right)$ and Student's T-test, with a $5 \%$ level for statistical significance.

Factors associated with cervical disease (HSIL/CA) were identified using multivariate logistic regression analysis, using the direct method to select variables. The model included variables whose univariate analysis showed $\mathrm{p}<0.25$ and those considered biologically important according to the literature 15. Adjustment of the model was evaluated by the Hosmer \& Lemeshow test. In all cases we refer first to the results of the positive group for high-grade or cancer and then to the negative group (without HSIL/CA).

The following exposure variables were studied: age, marital status, schooling, family income, history of STD, age at menarche and sexual debut, smoking, alcohol use, drug use, number of gestations, parity, age at first gestation, use of hormonal contraceptives, condom use, number of partners, and schooling and age of partners. We also analyzed the interval between menarche and sexual debut, in addition to the interval between sexual debut and diagnosis of SIL.

The study was approved by the Institutional Review Board/Research Ethics Committee of the Instituto Fernandes Figueira, Fundação Oswaldo Cruz. 


\section{Results}

Cytopathology reported squamous intraepithelial lesion in 20.5\% (95\%CI: 17.6-23.7) (Table 1). After this analysis, 34 patients without diagnostic confirmation by biopsy were excluded.

Cytological/histological concordance was $63.8 \%$ (false-positive cytology in $18.7 \%$ and falsenegative in $17.5 \%$ ). Figure 1 illustrates the sequence of events.

Based on the result of cervical histopathology, prevalence of intraepithelial lesions (LSIL + HSIL) in this sample of adolescents was $8.4 \%$ (95\%CI: 6.4-10.7). Prevalence of HSIL/CA was $3.0 \%$ (95\%CI: 1.8-4.6), as shown in Table 2.

SIL was observed in a short period of sexual activity, with a mean of 1.7 years ( $\mathrm{SD}=1.2$ years). The interval of up to two years between sexual debut and diagnosis of SIL showed a statistically significant difference $(\mathrm{p}=0.02)$, in agreement with the natural history of HPV-related diseases, in which LSIL is the earliest lesion. Importantly,
$57 \%$ of HSIL cases occurred in the first two years.

Table 3 shows the factors associated with pre-invasive and invasive disease of the uterine cervix (HSIL/CA), according to bivariate analysis. Among the demographic data, only age was associated (PR= 5.3; 95\%CI: 1.8-15.6): age $\geq 17$ years in $81 \%(17 / 21)$ of the positive group and $43.3 \%$ (280/647) of the negative group. As for gynecological history, the number of gestations was significant ( $\mathrm{PR}=4.2$; 95\%CI: $1.7-10.4$ ), as was age at first gestation ( $\mathrm{PR}=0.15 ; 95 \% \mathrm{CI}$ : 0.03-0.68).

Among the behavioral variables, none was associated with HSIL/CA. The number of partners varied from one to 52 , with one partner reported by $47.6 \%(10 / 21)$ in the positive group and $65.7 \%$ (425/647) in the negative group. On average, male partners were four years older than patients in both groups. History of STD was nearly three times more frequent in the positive group. Use of hormonal contraceptives was similar in the two groups $(66.6 \%=14 / 21$ and $68 \%=440 / 647)$. Condom use was infrequent in the two groups

Table 1

Distribution of cytopathology reports.

\begin{tabular}{lcc}
\hline Cytopathology reports & Frequency & $\mathbf{9 5 \% C l}$ \\
\hline LSIL & 122 & $17.4(14.6-20.4)$ \\
HSIL & 22 & $3.1(2.0-4.7)$ \\
Normal & 558 & $79.5(76.3-82.4)$ \\
Total & 702 & 100.0 \\
\hline
\end{tabular}

$\mathrm{LSIL}=$ low-grade squamous intraepithelial lesions; HSIL = High-grade squamous intraepithelial lesions.

Figure 1

Sequence of screening events (cytology-colposcopy-biopsy).

\begin{tabular}{|c|c|c|c|c|}
\hline $\begin{array}{l}\text { Cytology } \\
\text { Normal = } 558\end{array}$ & & Colposcopy & & Biopsy \\
\hline $\mathrm{HSIL}=22$ & $-2^{*} \longrightarrow$ & $\begin{array}{l}1 \text { normal } \\
19 \text { altered }\end{array}$ & $-2^{\star} \longrightarrow$ & $\begin{array}{l}13 \text { HSIL } \\
3 \text { LSIL } \\
1 \text { cancer }\end{array}$ \\
\hline $\mathrm{LSIL}=122$ & $-30 *$ & $\begin{array}{l}28 \text { normal } \\
64 \text { altered }\end{array}$ & & $\begin{array}{l}7 \mathrm{HSIL} \\
33 \mathrm{LSIL} \\
24 \text { not submitted to biopsy }\end{array}$ \\
\hline
\end{tabular}

\footnotetext{
* 34 adolescents were excluded from the final sample because they did not have diagnostic confirmation by biopsy.

$\mathrm{LSIL}=$ low-grade squamous intraepithelial lesions; HSIL = High-grade squamous intraepithelial lesions.
} 
Table 2

Prevalence of SIL/CA following histopathological analysis.

\begin{tabular}{lcc}
\hline Prevalence of SIL/CA & Frequency & $95 \% \mathrm{Cl}$ \\
\hline LSIL & $36 / 668$ & $5.4(3.8-7.4)$ \\
HSIL & $20 / 668$ & $3.0(1.8-4.6)$ \\
CA & $1 / 668$ & $0.15(0-0.8)$
\end{tabular}

$\mathrm{SIL} / \mathrm{CA}=$ squamous intraepithelial lesions/cervical cancer; $\mathrm{LSIL}=$ low-grade squamous intraepithelial lesions; HSIL = Highgrade squamous intraepithelial lesions; $C A=$ cervical cancer.

Table 3

Factors associated with uterine cervical disease *

Prevalence HSIL/CA

( $n=21)$
Prevalence ratio $(95 \% \mathrm{Cl})$

\begin{tabular}{|c|c|c|}
\hline \multicolumn{3}{|l|}{ Demographic data } \\
\hline \multicolumn{3}{|l|}{ Age } \\
\hline $12 \dashv 16 y$ & $1.1(4 / 371)$ & Reference \\
\hline $17 \dashv 19 y$ & $5.7(17 / 297)$ & $5.3(1.8-15.6)$ \\
\hline \multicolumn{3}{|c|}{ Family income (times minimum wage) } \\
\hline $1-4$ & $2.9(9 / 308)$ & $0.9(0.4-2)$ \\
\hline $4-30$ & $3.4(12 / 358)$ & Reference \\
\hline \multicolumn{3}{|l|}{ Marital status } \\
\hline Single & $2.8(16 / 579)$ & $0.5(0.2-1.3)$ \\
\hline Married/Marital union & $5.6(5 / 89)$ & Reference \\
\hline \multicolumn{3}{|l|}{ Schooling } \\
\hline Primary & $3.6(15 / 411)$ & $1.5(0.6-3.9)$ \\
\hline Secondary & $2.4(6 / 253)$ & Reference \\
\hline \multicolumn{3}{|l|}{ Partner's schooling } \\
\hline Primary & $3(11 / 367)$ & $1.3(0.5-3.6)$ \\
\hline Econdary & $2.2(6 / 270)$ & Reference \\
\hline \multicolumn{3}{|l|}{ Gynecological history } \\
\hline \multicolumn{3}{|l|}{ Menarche (age) } \\
\hline $9 \dashv 12$ & $2.5(11 / 432)$ & $0.6(0.3-1.4)$ \\
\hline $13-19$ & $4.2(10 / 236)$ & Reference \\
\hline \multicolumn{3}{|l|}{ Sexual debut age } \\
\hline $7 \dashv 14$ & $2.4(7 / 289)$ & $0.7(0.3-1.6)$ \\
\hline $15 \dashv 19$ & $3.7(14 / 379)$ & Reference \\
\hline \multicolumn{3}{|c|}{ Interval menarche-debut (years) } \\
\hline$<2$ & $3.6(12 / 336)$ & $1.3(0.6-3.0)$ \\
\hline $3-8$ & $2.7(9 / 332)$ & Reference \\
\hline \multicolumn{3}{|c|}{ Age at 1 st gestation $(n=151)$} \\
\hline $12 \nmid 15$ & $2.4(2 / 85)$ & $0.15(0.03-0.68)$ \\
\hline $16 \dashv 18$ & $15.2(10 / 66)$ & Reference \\
\hline \multicolumn{3}{|l|}{ Number of gestaions } \\
\hline zero & $1.7(9 / 517)$ & Reference \\
\hline 1 & $7.3(9 / 123)$ & $4.2(1.7-10.4)$ \\
\hline $2 \nmid 3$ & $10.7(3 / 28)$ & $6.1(1.7-21.5)$ \\
\hline \multicolumn{3}{|l|}{ Parity } \\
\hline zero & $2.6(15 / 573)$ & Reference \\
\hline $1 \dashv 2$ & $6.3(6 / 95)$ & $2.4(0.9-6.1)$ \\
\hline
\end{tabular}

Ag

$12-16 y$

$1(4 / 371)$

Reference

$2.9(9 / 308)$

$0.9(0.4-2)$

$.5(0.2-1.3)$

Reference

$1.5(0.6-3.9)$

Reference

$3(0.5-3.6)$

Reference

$0.6(0.3-1.4)$

.7 (0.3-1.6)

$3(0.6-3.0)$

Reference

$15(0.03-0.68)$

Reference

$2(1.7-10.4)$

Reference

(continues) 


\begin{tabular}{|c|c|c|}
\hline & $\begin{array}{l}\text { Prevalence HSIL/CA } \\
\qquad(n=21)\end{array}$ & Prevalence ratio $(95 \% \mathrm{Cl})$ \\
\hline \multicolumn{3}{|c|}{ Behavioral data } \\
\hline \multicolumn{3}{|c|}{ Number of partners } \\
\hline 1 & $2.3(10 / 435)$ & Reference \\
\hline $2 \dashv 52$ & $4.7(11 / 233)$ & $0.5(0.2-1.1)$ \\
\hline \multicolumn{3}{|c|}{ Age of current partner } \\
\hline $13 \nmid 20$ & $2.2(8 / 357)$ & $0.6(0.2-1.6)$ \\
\hline $21 \dashv 48$ & $3.5(10 / 282)$ & Reference \\
\hline \multicolumn{3}{|c|}{ Sexuality transmitted diseases } \\
\hline Yes & $8(2 / 25)$ & $2.7(0.7-11.0)$ \\
\hline No & $3(19 / 643)$ & Reference \\
\hline \multicolumn{3}{|c|}{ Hormonal contraception } \\
\hline Yes & $3.1(14 / 454)$ & Reference \\
\hline No & $3.2(7 / 214)$ & $1(0.4-2.3)$ \\
\hline \multicolumn{3}{|c|}{ Condom use } \\
\hline Yes & $1(1 / 102)$ & Reference \\
\hline No & $3.5(20 / 566)$ & $0.3(0.04-2.04)$ \\
\hline \multicolumn{3}{|c|}{ Alcohol abuse } \\
\hline Yes & $3.2(3 / 95)$ & $1(0.3-3.3)$ \\
\hline No & $3.2(18 / 566)$ & Reference \\
\hline
\end{tabular}

* The numeric variables were categorized by median;

** Times minimum wage.

and was three times less frequent in the positive group $(4.8 \%=1 / 21$ and $15.7 \%=101 / 647)$. Non-utilization of any contraceptive method was $28.6 \%(6 / 21)$ and $16.4 \%(106 / 647)$, respectively. In the negative group $(\mathrm{n}=647)$, smoking was reported by $11.7 \%$ (75) and drug use by $3.1 \%$ (20), with no report in the positive group.

According to the defined statistical criteria, the following variables were selected for the multivariate model: age, marital status, sexual debut, number of gestations, history of STD, and condom use. Although not significant in the preliminary analysis, number of partners was included because it appears as an important factor in the literature.

Results of the multivariate analysis demonstrated that the factors that remained associated with diagnosis of HSIL/CA were age and gestation. In relation to the adolescent's age, an increase of one year doubled the odds of cervical disease. Likewise, with each additional gestation, the adolescents had approximately twice the odds of HSIL/CA (Table 4). The model's fit according to the Hosmer \& Lemeshow test was $\chi^{2}=14.1(\mathrm{p}=0.08)$.

\section{Discussion}

In the current study, cytopathology agreed with histopathology in $63.8 \%$ of cases, similar to the results of Netto et al. 5 and Skehan et al. 16 (60.2\% and $64 \%$, respectively).

One of the most striking results in our study was the $8.4 \%$ SIL prevalence (95\%CI: 6.4-10.7), with a high prevalence of HSIL in adolescents (3\%). Mount \& Papillo 17 also reported a high prevalence of SIL (3.7\%) in 10,296 colpocytologies in adolescents as compared to the 20-29-year group (SIL $=3.5 \%$ ) and women over 30 years (SIL $=1.27 \%$ ). Utagawa et al. 18 , in a study from 1987 to 1995, found HSIL in $7.7 \%$ of their sample, noting that the prevalence of abnormal cytopathologies in adolescents almost quadrupled, while Roye 19 reported an increase from $2 \%$ in 1973 to $6 \%$ in 1978.

According to Moscicki 20, SIL rates among adolescents in the United States varied from 0.12 to $3 \%$ and tended to increase with the adolescent's age. In females under 16 years, the author found SIL in $0.78 \%$, while the rate increased to $2.5 \%$ by including females up to 19 years, which is consistent with our findings that increasing age in adolescents is associated with increased risk of cervical disease.

A longitudinal study by Schlecht et al. 21 also showed that SIL was more frequent in the 1824 -year group ( $R R=2.4 / 1,000$ women-months; 95\%CI: 1.7-3.2) than in the 35-44-year group (RR $=1.01$ ), leading us to conclude that development of persistent oncogenic HPV infection under 30 
Crude and adjusted odds ratio (OR) for association between cervical disease and selected variables.

\begin{tabular}{|c|c|c|c|}
\hline & $\begin{array}{l}\text { Crude OR } \\
(95 \% \mathrm{Cl})\end{array}$ & $\begin{array}{l}\text { Adjusted OR * } \\
(95 \% \mathrm{Cl})\end{array}$ & $\begin{array}{c}\text { Adjusted OR }(95 \% \mathrm{Cl}) \\
\text { final model }\end{array}$ \\
\hline Age & $2.3(1.5-3.4)$ & $2.0(1.2-3.4)$ & $2.0(1.3-3.1)$ \\
\hline Marital status & $0.5(0.2-1.3)$ & $1.0(0.3-3.0)$ & $\star \star$ \\
\hline Sexual debut age & $1.3(0.9-1.7)$ & $1.0(0.6-1.6)$ & $\star *$ \\
\hline Number of gestations & $2.9(1.7-5.0)$ & $2.2(1.1-4.4)$ & $2.3(1.3-4.1)$ \\
\hline Number of partners & $1.0(0.9-1.1)$ & $1.0(0.9-1.1)$ & $\star \star$ \\
\hline History of STDs & $2.8(0.6-13.0)$ & $3.5(0.8-18.0)$ & $\star \star \star$ \\
\hline Condom use & $0.3(0.03-2.1)$ & $0.4(0.05-3.3)$ & ** \\
\hline
\end{tabular}

* Multivariate model containing variables selected in univariate analysis;

** Excluded not statistically significant variable.

years of age leads to increased risk of persistent SIL $(\mathrm{RR}=19.8)$.

Increased frequency of SIL during adolescence has been attributed to early sexual initiation and differences in the biological maturity of the immune system and cervix; several authors have identified these factors as accounting for the increased susceptibility of the adolescent's uterine cervix to HPV infection 2,22,23,24.

We did not observe any difference between the two groups in terms of age at sexual debut (PR $=0.7)$ or age at menarche $(\mathrm{PR}=0.6)$. Various researchers have described a relationship between menarche-sexual debut interval and HPV infection and the development of SIL. Kahn et al. 22 raised the hypothesis that adolescents with SIL present delayed maturation of the cervical transformation zone with an increased area of immature epithelium, resulting in greater vulnerability to HPV infection and SIL. Beznos et al. 25 limit this interval to 18 months. Moscicki et al. 24 observed that women with SIL showed later age at menarche and a shorter menarche-sexual debut interval, but the difference was not statistically significant.

In our study, the menarche-sexual debut interval was approximately 2.6 years in the two groups and did not show an association with cervical disease. However, we observed the presence of SIL within a short period of sexual activity. A 50month cohort study by Moscicki et al. 26 showed that one out of four adolescents developed LSIL (total = 109) during follow-up.

A limitation we identified in our study was the fact that we did not have access to HPV DNA typing to identify the latent form of this infection, so that it was not possible to calculate the prevalence of HPV infection. Thus, our focus was the study of prevalence and factors associated with HPV-associated cervical disease. By obtaining a p-value of 0.08 in the Hosmer \& Lemeshow test, we can state that there is no evidence to reject the null hypothesis, i.e., that the observed frequencies are equal to the expected. However, our logistic regression model's fit was not ideal for explaining the associated factors, since an important variable was missing from the model (namely, presence of HPV infection). Inclusion of this variable could increase this logistic regression model's power to predict the occurrence of lesions in adolescents.

The current study showed an association between gestational number and HSIL/CA. These results reflect the observed data on contraception. We observed that barrier methods, especially condoms, are not the method of choice during adolescence in general, and they are even less frequently used in the disease-positive group. The higher proportion of non-utilization of any contraceptive method further explains the increased pregnancy rate in the group with cervical disease (28.6\% versus $16.4 \%)$.

Some authors have suggested that hormonal contraception could exert a potential effect on cervical carcinogenesis in older women, due to the greater exposure time 19,27. Ho et al. 28 report that oral contraceptives served as a protective factor and were associated with lower risk of subsequent HPV infection, reflecting a long, stable relationship with the same partner. Cox 29 reports a weak correlation, which does not justify interruption of the contraceptive method, since pregnancy could complicate treatment of the lesions.

In our caseload, we observed a single case with rapid evolution during pregnancy. At 18 
years of age, with the patient in her third gestation, cytopathology in the third month showed cervical intraepithelial neoplasia Grade 1 (CIN 1). The patient returned one month after giving birth, when she repeated her cytopathology, the report of which showed CIN 3, and the patient was submitted to a colposcopically-guided biopsy, with a diagnosis of micro-invasive carcinoma. The choice was to perform only a cone biopsy of the uterine cervix for diagnostic confirmation, due to the patient's age. Since the result showed stage IA2 squamous cell carcinoma, the choice was to complement the surgical therapy.

Age at first gestation showed a statistically significant difference in the bivariate analysis, which was not confirmed in the multivariate analysis. The latter showed the importance of the number of gestations, since with each new pregnancy the adolescents showed approximately twice the odds of presenting HSIL/CA. Numerous studies have associated age at first gestation and/or number of gestations with HPV infection, but there have been few reports on the relationship to cervical disease. Bosch et al. 30 suggest that age at first pregnancy is the most important risk factor. However, according to De Britton et al. 31 , the number of gestations is an adverse prognostic factor.

There appears to be greater consensus concerning the association between the number of partners and HPV infection. Ho et al. ${ }^{28}$ studied risk factors for a subsequent infection by another HPV type in a cohort of HPV-positive young women, concluding that there is an association with a large number of partners in the previous 7 to 12 months and a new infection in the 24 months of follow-up.

These data justify targeted orientation for female patients and their male partners with the objective of reducing transmission to other individuals. Both should be advised that they might be infective, even in the absence of visible lesions, since treatment of lesions does not eliminate HPV. In relation to the woman, studies suggest that testing the partner serves no practical purpose, since the male's role is minimal in re-infection, persistence of the infection, and relapses 32 .

However, few studies have estimated the relationship between number of partners and cervical disease. Chan et al. 33 observed that HPV-positive women with five or more partners present a lower probability of regression of lesions than those with fewer partners $(p=0.003)$. In the current study the number partners was not associated with HSIL/ CA, in agreement with Oyakawa et al. 34 .

According to a cohort study in adolescents by Moscicki et al. 26, the risk factors are different for HPV infection and LSIL. Multivariate analysis showed that risk factors for HPV infection included sexual behavior (OR $=10.1$ per new partner/month), history of herpes simplex virus (OR $=3.54)$, and history of vulvar warts $(\mathrm{OR}=2.7)$. Factors associated with the development of LSIL in multivariate analysis were smoking $(\mathrm{OR}=1.6)$ and presence of HPV infection (less than one year: $\mathrm{OR}=7.4 ; 1$ to 2 years: $\mathrm{OR}=10.2$, and 2 to 3 years: $\mathrm{OR}=6.1$ ).

In relation to smoking, there were no reports of this habit in the positive group. Several other authors have also failed to show such an association 30,35,36. Brinton 37 did not observe an association with LSIL, but suggests that smoking could be a co-factor for the development of HSIL, showing an association with time of exposure to smoking and number of cigarettes per day, in agreement with other authors 27,38 . Since our study included only adolescents, there was not an extended exposure to tobacco, and this may explain why we did not find such an association.

In our study, level of alcohol use was the same in the two groups. Bairati et al. 39 found a moderate but significant correlation between the amount of alcoholic beverages consumed and the risk of HPV infection. We found no report of illicit drug use in the HSIL/CA positive group, in agreement with Moscicki et al. 26.

To allow generalization of these results, we attempted to identify similar characteristics between the study population and the overall resident population of female adolescents in the State of Rio de Janeiro, based on 2000 census data from the National Census Bureau (Instituto Brasileiro de Geografia e Estatística) ${ }^{40}$. In relation to family income, the nominal mean monthly income of heads of private households in the State of Rio de Janeiro in 2000 was BRL 969.55, as compared to BRL 768.83 for the country as a whole. Considering that the prevailing minimum wage at the time was BRL 180.00 (approximately US\$81.00), this represents 5.4 and 4.3 times the minimum wage, respectively, which is similar to the income profile in our study population. In relation to marital status, we were only able to access the data for the national population as a whole. In 2000 there were a total of 17,491,113 adolescent females in Brazil, of whom 1,396,890 were married or in marital union, representing $8 \%$ of the total, which is less than in our study but similar to the total population treated. Unfortunately there were no available data on the other variables, thus limiting the possibility of generalizing the results to the population of the State of Rio de Janeiro or even that of Brazil as a whole. However, we believe that these results can be generalized to adolescents in the munici- 
pality of Rio de Janeiro who seek gynecological care in public health services. The analysis of our study population did not identify any factors that might have generated any selection bias, since the age bracket treated is wide, the outpatient profile includes general gynecological care without any type of triage for specific diseases, the population is geographically limited, and there are no other public health care services in the area that treat this population.

We conclude that adolescent females fail to adequately practice hormonal contraception and that condoms are rarely used, thus resulting in increased incidence of pregnancy, STD, and SIL. Factors associated with the development of highgrade intraepithelial lesions and cervical cancer are age and number of gestations, doubling the odds of occurrence of such lesions with each year increase in the patient's age, as well as with each new pregnancy. In addition, we observed a short time interval between sexual debut and diagnosis of SIL, which urges us to continue our research by developing a new study with a longitudinal design on the natural history of squamous intraepithelial lesion in adolescence in order to confirm our findings.

The high prevalence of SIL in our results suggests the importance of including sexually active adolescents in the National Cervical Cancer Program (Programa Viva Mulher) for the early detection and treatment of these lesions, thus avoiding early harm to women's health.

\section{Resumo}

O objetivo foi descrever a freqüência e os fatores associados ao câncer cervical (CA) e lesões escamosas intra-epiteliais de alto grau (HSIL) entre adolescentes. Realizou-se estudo transversal com 702 adolescentes sexualmente ativas, assistidas em um hospital geral no Rio de Janeiro, Brasil, entre 1993 e 2002. A investigação foi realizada através de citopatologia e colposcopia, e a confirmação por biópsia cervical. As variáveis de exposição foram características sociais e demográficas, e aquelas relacionadas à saúde reprodutiva, hábitos e comportamento sexual. Baseado nos achados histopatológicos, a freqüência de HSIL/CA foi 3\% (IC95\%: 1,84,6). Houve um caso de cancer invasivo. A cada nova gestação, a chance de HSIL/CA aumentava 2,2 vezes (IC95\%: 1,1-4,4). A idade também esteve associada com este resultado (OR = 2,0; IC95\%: 1,2-3,4), dobrando a cada ano de idade a chance de adquirir este nível da doença. A freqüência de lesões cervicais intraepiteliais sugere a importância de incluir adolescentes sexualmente ativas nos programas de prevenção do câncer cervical, com o objetivo de detectar e assegurar o tratamento precoce destas lesões.

Neoplasias do Colo do Útero; Papillomavirus Humano; Adolescente

\section{Contributors}

D. L. M. Monteiro participated in the overall study concept, data collection, data analysis, and drafting of the article. A. J. B. Trajano providing critical reviews throughout the thesis development process and final drafting of the article. K. S. Silva and F. B. Russomano collaborated in the study design, elaboration, and implementation of the statistical analysis and review of the manuscript. 


\section{References}

1. Parkin DM, Pisani P, Ferlay J. Estimates of the world wide incidence of 25 major cancers in 1990. Int J Cancer 1999; 80:827-41.

2. Deligdisch L, Miranda CRR, Wu HS, Gil J. Human papillomavirus-related cervical lesions in adolescents: a histologic and morphometric study. Gynecol Oncol 2003; 89:52-9.

3. Ferenczy A, Franco EL. Persistent human papillomavirus infection and cervical neoplasia. Lancet Oncol 2002; 3:11-6.

4. Instituto Nacional de Câncer. Estimativas de incidência e mortalidade por câncer no Brasil. Rio de Janeiro: Instituto Nacional de Câncer; 2005.

5. Roberto-Neto AR, Ribalta JCL, Focchi J, Baracat EC. Avaliação dos métodos empregados no Programa Nacional de Combate ao Colo Uterino do Ministério da Saúde. Rev Bras Ginecol Obstet 2001; 23:209-16.

6. Instituto Nacional do Câncer. Programa Nacional de Controle do Câncer do Colo do Útero e de Mama - Viva Mulher. Prevenção e Detecção 2002. http://www.inca.gov.br/prevencao/programas/ pncccum/htlm (acessado em 30/Jun/2003).

7. Melkert PW, Hopman E, van den Brule AJ, Risse EK, van Diest PJ, Bleker OP, et al. Prevalence of HPV in cytomorphologically normal cervical smears, as determined by the polymerase chain reaction, is age-dependent. Int J Cancer 1993; 53:919-23.

8. Morrison EA, Ho GY, Vermund SH, Goldberg GL, Kadish AS, Kelley KF, et al. Human papillomavirus infection and other risk factors for cervical neoplasia: a case-control study. Int J Cancer 1991; 49:6-13.

9. Sociedade Brasileira de Citopatologia. Capítulo do Rio Grande do Sul. Prevalência do papilomavírus humano no câncer de colo uterino: uma perspectiva mundial. http://www.tca.com.br/cito-rs/atu. htm (acessado em 01/Fev/2002).

10. Alford S. Adolescents - at risk for sexually transmitted infections. American Social Health Association. http://www.ashastd.org (acessado em 10/ Set/2003).

11. Lüdicke F, Stalberg A, Vassilakos P, Major AL, Campana A. High and intermediate-risk human Papillomavirus infection in sexually active adolescent females. J Pediatr Adolesc Gynecol 2001; 14:171-4.

12. Bjørge T, Gunbørud AB, Langmark F, Skacre GB, Thoresen SO. Cervical mass screening in Norway - 510,000 smers a year. Cancer Detect Prev 1994; 18:463-70.

13. Sadegui SB, Hsieh EW, Gunn SW. Prevalence of cervical intraepithelial neoplasia in sexually active teenagers and young adults. Am J Obstet Gynecol 1984; 148:726-9.

14. Gonçalves WC, Leonardo NDB, Serapião JJ. Influência atual do HPV na sexualidade. Femina 2003; 31:823-5.

15. Hosmer DW, Lemeshow S. Applied logistic regression. New York: Wiley-Interscience Publication; 1989.

16. Skehan M, Soutter WP, Lim MK, Krausz T, Pryse-Davies J. Reliability of colposcopy and directed punch biopsy. Br J Obstet Gynaecol 1990; 97: 811-6.
17. Mount SL, Papillo JL. A study of 10296 pediatric and adolescent Papanicolaou smear diagnoses in northern New England. Pediatrics 1999; 103:539-45.

18. Utagawa ML, Pereira SM, Cavaliere MJ, Maeda MY, Shih LW, Shirata NK. Cervical intraepithelial neoplasia in adolescents: study of cytological findings between 1987 and 1995 in Sao Paulo State-Brazil. Arch Gynecol Obstet 1998; 262:59-64.

19. Roye CF. Abnormal cervical cytology in adolescents: a literature review. J Adolesc Health 1992; 13:643-50.

20. Moscicki AB. Genital HPV infections in children and adolescent. Obstet Gynecol Clin North Am 1996; 23:675-97.

21. Schlecht NF, Kulaga S, Robitaille J, Ferreira S, Santos M, Miyamura RA, et al. Persistent human papillomavirus infection as a predictor of cervical intraepithelial neoplasia. JAMA 2001; 286:3106-14.

22. Kahn JA, Rosenthal SL, Succop PA, Ho GYF, Burk $\mathrm{RD}$. The interval between menarche and age of first sexual intercourse as a risk factor for subsequent HPV infection in adolescent and young adult women. J Pediatr 2002; 141:718-23.

23. Shew ML, Fortenberry JD, Miles P, Amortegui AJ. Interval between menarche and first sexual intercourse related to risk of human papillomavirus infection. J Pediatr 1994; 125:661-6.

24. Moscicki AB, Winkler B, Irwin C, Schachter J. Differences in biologic maturation, sexual behavior, and sexually transmitted disease between adolescents with and without cervical intraepithelial neoplasia. J Pediatr 1989; 115:487-93.

25. Beznos GW, Alonso FJF, Carvalho MZM. HPV em outras especialidades. Epidemiologia, diagnóstico e tratamento. In: Carvalho JJM, Oyakawa N, organizadores. Consenso brasileiro de HPV. 1a Ed. São Paulo: BG Cultural; 2000. p. 74-86.

26. Moscicki AB, Hills N, Shiboski S, Powell K, Jay N, Hanson E, et al. Risks for incident human papillomavirus infection and low-grade squamous intraepithelial lesion development in young females. JAMA 2001; 285:2995-3002.

27. Castellsague X, Bosch FX, Munoz N. Environmental co-factors in HPV carcinogenesis. Virus Res 2002; 89:191-9.

28. Ho GYF, Studentsov Y, Hall CB, Bierman R, Beardsley L, Lempa M, et al. Risk factors for subsequent cervicovaginal human papillomavirus infection and the protective role of antibodies to HPV-16 virus-like particles. J Infect Dis 2002; 186:737-42.

29. Cox JT. Epidemiology of cervical intraepitelial neoplasia: the role of human papillomavirus. Clin Obstet Gynaecol 1995; 9:137.

30. Bosch FX, Muñoz N, de Sanjose S, Izarzugaza I, Gili M, Viladiu P, et al. Risk factors for cervical cancer in Colombia and Spain. Int J Cancer 1992; 52:750-8.

31. De Britton RC, Hildesheim A, De Lao S, Brinton LA, Sathya P, Reeves WC, et al. Human papillomavirus and other influences on survival from cervical cancer in Panama. Obstet Gynecol 1993; 81:19-24. 
32. Coordenação Nacional de DST/AIDS. Manual de DST. Infecção pelo Papilomavírus humano (HPV). http://www.aids.gov.br/assistencia/manualdst/ item10.htm (acessado em 13/Abr/2003).

33. Chan JK, Monk BJ, Brewer C, Keefe KA, Osann K, McMeekin S, et al. HPV infection and number of lifetime sexual partners are strong predictors for natural regression of CIN 2 and 3. Br J Cancer 2003; 89:1062-6.

34. Oyakawa N, Dias AR, Okada MMK, Nobumoto CT, Ramos LO, Pinotti JA. Avaliação de pacientes menores de 20 anos com neoplasia intraepitelial do trato genital inferior. Rev Bras Ginecol Obstet 1998; 9:25-7.

35. Koutsky LA, Holmes KK, Critchlow CW, Stevens CE, Paavonen J, Beckmann AM, et al. A cohort study of the risk of cervical intraepithelial neoplasia grade 2 or 3 in relation to papillomavirus infection. $\mathrm{N}$ Eng J Med 1992; 327:1272-8.
36. Diakomanolis E, Elsheikh A, Voulgaris Z, Rodolakis A, Vlachos G, Michalas S. Cervical intraepithelial neoplasia in the Young female. Diagnosis and management. Eur J Gynaecol Oncol 2001; 22: 236-7.

37. Brinton LA. Epidemiology of cervical cancer - overview. IARC Sci Publ 1992; (119):3-23.

38. Roteli-Martins CM, Derchain SFM, Dores GB, Siqueira SAC, Alves VF, Panetta K. Associação entre diversos tipos de DNA-HPV e outras infecções vaginais com lesões intra-epiteliais cervicais de alto grau. Rev Bras Ginecol Obstet 1997; 19:363-7.

39. Bairati I, Sherman KJ, McKnight B, et al. Diet and genital warts: a case-control study. Sex Transm Dis 1994; 21:149-54.

40. Instituto Brasileiro de Geografia e Estatística. Censo demográfico, 2000. http://www.ibge.gov.br/ (acessado em 10/Fev/2004).

Submitted on 25/May/2005

Final version resubmitted on 28/Nov/2005

Approved on 11/Dec/2005 